\title{
Internationalization of Higher Vocational Education in Yunnan Province under the Belt and Road Initiative
}

\author{
Ying Zhao \\ Zhonghua Vocational College \\ Yunnan University of Finance and Economics \\ Kunming, China \\ yinduoes@qq.com
}

\author{
Fan $\mathrm{Yu} *$ \\ Business School \\ Yunnan University of Finance and Economics \\ Kunming, China \\ bpippen@163.com
}

\begin{abstract}
There is an important developmental opportunity for internationalization of higher vocational education in Yunnan Province under the B\&R Initiative. Rationales for internationalization and the present condition of it are presented. According to the analytical framework for internationalization, internationalization strategies of higher vocational education in Yunnan are proposed in four aspects including governance, operations, services and human resources.
\end{abstract}

Keywords-Internationalization of higher vocational education; Yunnan Province; the Belt and Road Initiative

\section{INTRODUCTION}

The Belt and Road (B\&R) Initiative was unveiled in 2013 in announcements revealing the "Silk Road Economic Belt" and "Maritime Silk Road", focusing on connectivity and cooperation of Asian, European and African continents and their adjacent seas. The B\&R Initiative aims to establish and strengthen partnerships among the countries along the Belt and Road, set up all-dimensional connectivity networks, and realize diversified, independent, balanced and sustainable development in these countries. The connectivity projects of the Initiative will help enhance people-to-people and cultural exchanges, and mutual learning among the peoples of the relevant countries, and enable them to understand, trust and respect each other and live in harmony, peace and prosperity[1]. The B\&R Initiative has been an important wakeup call for higher education in these areas, and the international activities of universities dramatically expanded in complexity, volume and scope. These activities stress upgrading the international skills and perspectives of students, providing cross-cultural understanding, and enhancing foreign language programs.

"Internationalization" has been used for centuries in political science, but its popularity in the education sector has really soared only since 1980 s, when it was commonly defined in terms of a set of activities at the institutional level. Then it is increasingly clear that internationalization needs to be understood both at the national/sector level and also the institutional level. Knight proposed that internationalization refers to "the process of integrating an international, intercultural or global dimension into the purpose, functions or delivery of higher education at the institutional and national levels" [2].

Internationalization is one of the major forces shaping and impacting higher vocational education as it changes to meet the challenges under the B\&R Initiative. The mobility of the labor force, the knowledge economy, and increased trade in services are driving Yunnan Province to place more importance on developing highly qualified brain power through international vocational education initiatives.

\section{RATIONALES FOR INTERNATIONALIZATION OF HIGHER VOCATIONAL EDUCATION IN YUNNAN PROVINCE}

Rationales, which are the driving force why a country, university, or institution wants to invest in internationalization, are reflected in the policies and programs that are eventually implemented. The necessity of having explicit rationales for internationalization cannot be overstated. Anticipated benefits of internationalization differ from country to country and from institution to institution, but internationalization is generally considered to make a contribution to the quality and relevance of higher education in a more interconnected world. Traditional nonprofit universities wish to enhance research and knowledge capacity and to increase cultural understanding [3] Another key motive for most internationalization projects is earning money. Countries are showing increased interest in the potential for exporting education for economic benefit. International graduate students also provide teaching and research services for modest compensation. And international students spend significant amounts of money in the host countries [4]. Rationales for internationalization of higher vocational education in Yunnan are presented in four aspects.

\section{A. Contributing to Promote the Opening of Vocational Education}

Education bears the heavy responsibility of cultural exchanges and personnel training. Strengthening education exchanges and cooperation is an inexhaustible motive force for continuously deepening the strategic partnership between China and the countries along the Belt and Road. Yunnan Province, adjacent to Southeast Asia, has actively carried out

*Corresponding author 
exchanges and cooperation in vocational education, which has become a new bright spot in the bilateral and multilateral cooperation. This promotes the opening up of vocational education in Yunnan, forming a new stage of internationalization in a larger, broader and higher level.

\section{B. Contributing to Deepen Bilateral Cooperation in Diverse}

With the increase of bilateral trade between China and Southeast Asian countries, Yunnan will surely be a major force and beneficiary of key projects such as connectivity, industrial cooperation, maritime cooperation, and financial cooperation. In the face of opportunities and challenges, Yunnan has taken full advantage of its role as a bridgehead in Southeast Asia, and has carried out the brand project of modern vocational education with the support of the China-Southeast Asian Vocational Education Forum. The project promotes multilateral cooperation in education, culture, finance and other areas between China and Southeast Asian countries to form a normalized cooperation and exchange mechanism.

\section{Contributing to Serve Economic and Social Development}

An educated workforce and citizenry, and the capacity to generate new knowledge are key components of a country's nation-building agenda. International academic projects have been considered an important contribution to the nationbuilding efforts of a developing country.

In recent years, a number of strategic emerging industries have risen rapidly, and new growth points have been formed in regional and industrial development. Chinese enterprises now have an unprecedented opportunity to enter foreign markets. Under the new situation, it requires a large number of outstanding talents who are impressively knowledgeable about local customs of host countries and understand international rules. Vocational education in Yunnan undertakes the mission of cultivating highly qualified laborers and technical talents. It is a manpower support for the economic and social development of China and Southeast Asian countries and is conducive to the promotion of regional economic integration.

\section{Contributing to Maintain the Stability and Harmony of the Borderland}

China and Southeast Asian countries are geographically close, culturally connected, business-affiliated, and mutually beneficial. Yunnan, a border area, is a bridgehead for exchanges and cooperation between China and Southeast Asia. Vocational education in Yunnan is focused on cultivating multilevel and diversified high-quality technical talents. In order to improve the professional quality of laborers in the border areas, Yunnan has to assume more responsibility and responsibilities. Vocational education in Yunnan should transform the advantages of human resources into the dividends of talents.

\section{THE PRESENT CONDITION OF INTERNATIONALIZATION OF HIGHER VOCATIONAL EDUCATION IN YUNNAN PROVINCE}

\section{A. Current Situation}

By the end of 2016, in Yunnan there were 41 vocational colleges with 255,000 students, 410 vocational schools with
618,000 students and 9,334 vocational technical training institutions with 4.37 million students [5]. The modern vocational education system is basically completed from the middle vocational and vocational colleges to the application of technical colleges. In terms of internationalization of higher education, many vocational colleges in Yunnan Province have learned from advanced foreign vocational education concepts, introduced common international industry standards, actively carried out international exchanges and cooperation, and have done a lot of practical work (Table I). The internationalization of higher vocational education in Yunnan is embodied in the following aspects.

\section{1) Management internationalization}

Higher vocational colleges in Yunnan Province plan to enhance the international vision and improve the capacity of international management so that the international education can be realized. Since 2006, these colleges have actively responded to the provincial government's call and established specialized institutions one after another. These institutions are named like International Exchange Center or International Cooperation and Exchange Department. They are responsible for the colleges' international academic exchanges, the appointment of foreign experts, foreign affairs management and so on. In accordance with the policies and regulations, a number of institutions have established school regulations such as the "Administrative Measures for Foreign Teachers", "Administrative Measures for Chinese-Foreign Cooperation", and "Administrative Measures for Foreign Students", to further standardize the process of internationalization of higher vocational education.

\section{2) Teachers internationalization}

Teachers internationalization includes implementing overseas visiting, implementing the introduction of foreign experts, enhancing national and provincial scholarship project application, encouraging the group and individual research projects, encouraging teachers to participate in international vocational education academic exchange activities, and constructing guidance mechanism. According to professional needs, these colleges sent teachers to foreign universities to study or give lectures, and invited scholars from many countries to show their latest academic research results.

\section{3) Students internationalization}

Many higher vocational colleges in Yunnan province have signed agreements with foreign organizations and schools to carry out exchanges and cooperation. The cooperation partners have spread across more than a dozen countries including the United Kingdom, France, Canada, Russia, South Korea, Thailand, Laos, Myanmar, the United States, Japan, Sweden and Malaysia. The growing demand for higher vocational education in these countries has led to an unprecedented interest in cross-border education. The cooperation modes include intensifying the implementation of intercollegiate exchange programs among students, participating in the international competition, encouraging students' overseas internship programs and so on. For the cultivation of foreign students, these colleges will take measures to enhance their attraction for foreign students, to improve education quality and to expand the scale of foreign students gradually. 


\section{4) Professional internationalization}

The internationalization of professionalism is mainly to add specialties and courses in line with international vocational education, and to increase international content in existing courses. Basing on the superior specialties, the colleges enhance the sino-foreign cooperation in running schools at abroad, implement the international general vocational qualification certificate project, construct the pilot specialty for international education, develop international professional teaching standards, construct international specialized courses and so on. Besides, some colleges are planning to carry out varieties of cooperation with advanced universities, colleges, companies and institutions all over the world. And lots of colleges are devoting more effort to strengthen foreign language teaching. These colleges pay great attention to the cultivation of English communication skills and increases the proportion of credit in English subjects. Because Yunnan Province faces Southeast Asia, some vocational high vocational colleges have set up majors in Thai and other minor languages according to the actual situation of themselves.

TABLE I. PRACTICE OF INTERNATIONALIZATION OF HIGHER VOCATIONAL EDUCATION IN YUNNAN PROVINCE

\begin{tabular}{|c|c|c|c|c|c|c|c|c|}
\hline No. & Higher Vocational College & $\begin{array}{c}\text { International } \\
\text { Office }\end{array}$ & $\begin{array}{c}\text { Policies } \\
\text { and } \\
\text { Regulation } \\
\text { s }\end{array}$ & $\begin{array}{l}\text { Foreign } \\
\text { Teachers }\end{array}$ & $\begin{array}{l}\text { Oversea } \\
\text { Studying } \\
\text { Activities }\end{array}$ & $\begin{array}{c}\text { International } \\
\text { Programme }\end{array}$ & $\begin{array}{c}\text { Sino - Foreign } \\
\text { Cooperative } \\
\text { Education }\end{array}$ & $\begin{array}{l}\text { Academic } \\
\text { Exchange }\end{array}$ \\
\hline 1 & Zhonghua Vocational College of YUFE & $\sqrt{ }$ & & & $\sqrt{ }$ & & $\sqrt{ }$ & $\sqrt{ }$ \\
\hline 2 & $\begin{array}{c}\text { City College of Kunming University of Science and } \\
\text { Technology }\end{array}$ & $\sqrt{ }$ & $\sqrt{ }$ & & $\sqrt{ }$ & $\sqrt{ }$ & $\sqrt{ }$ & $\sqrt{ }$ \\
\hline 3 & The Vocational and Technical Education College of YNNU & & & & $\sqrt{ }$ & & & $\sqrt{ }$ \\
\hline 4 & $\begin{array}{c}\text { Yunnan University of Nationalities School of Vocational \& } \\
\text { Technical Education }\end{array}$ & & & & $\sqrt{ }$ & $\sqrt{ }$ & $\sqrt{ }$ & $\sqrt{ }$ \\
\hline 5 & Kunming Metallurgy College & $\sqrt{ }$ & $\sqrt{ }$ & $\sqrt{ }$ & $\sqrt{ }$ & $\sqrt{ }$ & $\sqrt{ }$ & $\sqrt{ }$ \\
\hline 6 & Yunnan College of Business Management & $\sqrt{ }$ & $\sqrt{ }$ & $\sqrt{ }$ & $\sqrt{ }$ & $\sqrt{ }$ & $\sqrt{ }$ & $\sqrt{ }$ \\
\hline 7 & Yunnan Technology and Business University & $\sqrt{ }$ & $\sqrt{ }$ & $\sqrt{ }$ & $\sqrt{ }$ & $\sqrt{ }$ & $\sqrt{ }$ & $\sqrt{ }$ \\
\hline 8 & Yunnan Urban Construction Vocational College & $\sqrt{ }$ & $\sqrt{ }$ & $\sqrt{ }$ & $\sqrt{ }$ & $\sqrt{ }$ & $\sqrt{ }$ & $\sqrt{ }$ \\
\hline 9 & $\begin{array}{l}\text { Yunnan Vocational College of Mechanical and Electrical } \\
\text { Technology }\end{array}$ & $\sqrt{ }$ & $\sqrt{ }$ & $\sqrt{ }$ & $\sqrt{ }$ & $\sqrt{ }$ & & $\sqrt{ }$ \\
\hline 10 & Yunnan Vocational and Technical College of Agriculture & $\sqrt{ }$ & $\sqrt{ }$ & $\sqrt{ }$ & $\sqrt{ }$ & $\sqrt{ }$ & $\sqrt{ }$ & \\
\hline 11 & Yuxi Agriculture Vocation-Technical College & & & $\sqrt{ }$ & & $\sqrt{ }$ & & \\
\hline 12 & Xishuangbanna Vocational and Technical College & $\sqrt{ }$ & $\sqrt{ }$ & $\sqrt{ }$ & $\sqrt{ }$ & $\sqrt{ }$ & $\sqrt{ }$ & $\sqrt{ }$ \\
\hline 13 & Yunnan Jiaotong College & $\sqrt{ }$ & $\sqrt{ }$ & $\sqrt{ }$ & $\sqrt{ }$ & $\sqrt{ }$ & $\sqrt{ }$ & $\sqrt{ }$ \\
\hline 14 & Kunming Professional College of Arts & $\sqrt{ }$ & & $\sqrt{ }$ & & & & $\sqrt{ }$ \\
\hline 15 & Yunnan Vocational Institute of Energy Technology & $\sqrt{ }$ & $\sqrt{ }$ & $\sqrt{ }$ & & & & \\
\hline 16 & Baoshan College of Traditional Chinese Medicine & $\sqrt{ }$ & & $\sqrt{ }$ & $\sqrt{ }$ & $\sqrt{ }$ & & $\sqrt{ }$ \\
\hline 17 & Lijiang Teachers College & $\sqrt{ }$ & $\sqrt{ }$ & $\sqrt{ }$ & $\sqrt{ }$ & & & \\
\hline 18 & West Yunnan University & $\sqrt{ }$ & $\sqrt{ }$ & $\sqrt{ }$ & $\sqrt{ }$ & $\sqrt{ }$ & & $\sqrt{ }$ \\
\hline 19 & Lincang Normal College & & & $\sqrt{ }$ & & & & \\
\hline
\end{tabular}

\section{B. Advantages}

Firstly, the Ministry of Education released "the Action Plan for the Innovation and Development of Higher Vocational Education (2015-2018)" in 2015, which requires higher vocational colleges to expand cooperation with the countries along the Belt and Road. The B\&R Initiative has injected a new force into Yunnan's higher vocational education and will continue to promote the development of it.

Secondly, As economies around Asia globalize, and previously closed Southeast Asian markets open, growth through the Southeast Asian market expansion has become an increasingly popular strategy. The rapidly developing technology industry urgently needs the support of high-skilled talent teams. However, due to the limitations of its traditional education concepts and teaching capabilities, the existing skilled human resources are far from meeting the needs of the market. At the same time, more and more high-quality Chinese enterprises have landed in Southeast Asia, such as China Construction Bank, Country Garden, HUAWEI, MI and so on. Higher vocational colleges in Yunnan Province can break through the geographical restrictions and cooperate with local enterprises or Chinese enterprises that have already entered the Southeast Asian markets.

Thirdly, there has been frequent cooperation between the national governments of China and Southeast Asian countries 
in the field of higher vocational education in recent years. The "China-ASEAN Education Week" sponsored by the Ministry of Education provides an interactive platform for China's higher vocational education to move toward the Southeast Asia. At present, China has set up vocational education and training centers for these countries in many provinces, including Yunnan. The intergovernmental dialogue and cooperation has provided strong official support for the development of vocational education in Yunnan and is conducive to the longterm stable development of higher vocational education in Southeast Asia.

\section{Disadvantages}

At present, Yunnan's vocational education exchanges and cooperation with Southeast Asian countries are limited to the projects of student exchanges, teacher training, basic skills training. High-level cooperation such as the international occupation qualification interconnection and certification framework has not been established. The curriculum and teaching activities have not been set up in accordance with the characteristics of the colleges and the needs of regional economic development.

Yunnan's economy, culture, education and technology all lag behind the developed regions in the east. The vocational colleges in Yunnan are relatively weak in international competitiveness. They lack international standards for teaching quality and student professional competence, and the teachers with international education background are not enough. The internationalization of higher vocational colleges in Yunnan is generally lack of strategic thinking and the overall level needs to be improved.

\section{INTERNATIONALIZATION STRATEGIES OF HIGHER VOCATIONAL EDUCATION IN YUNNAN PROVINCE}

Strategies are at the core of the success and sustainability of internationalization. According to the analytical framework for internationalization proposed by J.Knight [6], internationalization strategies of higher vocational colleges in Yunnan can be presented in four aspects.

\section{A. Governance}

Governance strategies include: articulated rationale and goals for internationalization, active involvement of faculty and staff, expressed commitment by senior leaders, recognition of the international dimension in institutional mission/mandate statements, and in planning, management, and evaluation policy documents. Managers of higher education institutions should have an international vision. They should start building vocational education alliances, production and education alliances, regional alliances, and cultural alliances.

\section{B. Operations}

Operation strategies include: appropriate organizational structures; integrated into institution-wide and college-level planning, budgeting, and quality review systems; balance between centralized and decentralized promotion and management of internationalization; formal and informal systems for communication, coordination and liaison; adequate financial support and resource allocation systems. The government should work with the colleges to establish internal and external joint mechanisms, including negotiation mechanisms, interest distribution mechanisms, and knowledge sharing mechanisms, in order to standardize the internationalization. Yunnan have very obvious geographical advantages with Southeast Asia. These countries and regions are the key directions for the development of vocational education cooperation in Yunnan.

\section{Services}

Service strategies include: support from institution-wide service units, i.e., student housing, registration, alumni, information technology; student support services for incoming and outgoing students, i.e., orientation programs, counseling, cross-cultural training, visa advice; involvement of academic support units, i.e., library, faculty and staff training, research services. Higher vocational colleges should provide counseling and technical services for the sustainable development of students in countries along the Belt and Road. In particular, it is necessary to effectively link and introduce industry standards in these countries, and establish an international vocational education quality system. It is important to focus on improving the skills, attitudes, and cultural qualities of teachers and students, and pay attention to enhancing the awareness of globalization and cross-cultural communication.

\section{Human Resources}

Human resource strategies include: recruitment and selection procedures that recognize international expertise; faculty and staff professional development activities; reward and promotion policies to reinforce faculty and staff contributions; support for international assignments and sabbaticals. The ultimate goal of the internationalization of higher vocational education is to train international talents with a global perspective, understanding of international conventions, familiarity with industry characteristics, and strong language skills [7]. Higher vocational talent training standards should be integrated into the training requirements of foreign companies Colleges should actively promote the international professional qualification certification system, docking personnel training, professional settings, curriculum standards, and cultural exchanges. Finally, it will make overall plans for the establishment of partnerships for the certification and appraisal of professional qualification certificates between China and the countries along the Belt and Road.

\section{CONCLUSION}

Internationalization is one of the major forces shaping and impacting higher vocational education in Yunnan under the $\mathrm{B} \& \mathrm{R}$ Initiative. It is impossible to quantify the earnings of internationalization. But the earnings are undoubtedly large because knowledge industries often form an important part of the total economy. Calculating the impact of international activities is also difficult, but again the amount is large and rapidly growing. Yunnan Province should place more importance on developing international vocational education initiatives in four aspects, including governance, operations, services and human resources, thus to promote the internationalization process comprehensively, and achieve its sustainable and long-term development. 


\section{ACKNOWLEDGMENT}

We would like to thank Professor Lu and Professor Liu, for their valuable comments that help us improve this paper.

\section{REFERENCES}

[1] National Development and Reform Commission, Ministry of Foreign Affairs, and Ministry of Commerce of the People's Republic of China, 'Action plan on the China-proposed Belt and Road Initiative', 2015.

[2] J. Knight, S. Publishers, "Higher Education in Turmoil", Comparative \& International Education , pp. 21, 2008.

[3] P. G. Altbach, J. Knight, 'The Internationalization of Higher Education: Motivations and Realities', Journal of Studies in International Education, vol. 3, pp. 103-130, 2006.

[4] T. M. Davis, "Atlas of student mobility", New York: Institute of International Education, 2003.

[5] H. Y. Liu, Q. Y. He, "Consultation, Contribution and Shared Benefits, promote the integration of vocational education for South and Southeast Asia”, Journal of Yunnan Education, vol. 1, pp. 14-16, 2018.

[6] J. Knight, S. Publishers, "Higher Education in Turmoil", Comparative \& International Education , pp. 34, 2008

[7] S. Lester, "Sequential schooling or lifelong learning? International frameworks through the lens of English higher professional and vocational education", Education \& Training, vol. 60, pp. 213-224, 2018 